\title{
Formulation and Characterization of Antibacterial Hydrogels Based on Polyurethane Microstructures and 1,2,4-Triazole Derivatives
}

\begin{abstract}
LAVINIA MOLERIU1", ADINA OCTAVIA DUSE ${ }^{1 *}$, FLORIN BORCAN2*, CODRUTA SOICA ${ }^{2}$, LUDOVIC KURUNCZI ${ }^{2,3}$, MIRELA NICOLOV', MARIUS MIOC 2,3

${ }^{1}$ Victor Babes University of Medicine and Pharmacy Timisoara, Faculty of Medicine, $2^{\text {nd }}$ Eftimie Murgu Sq., 300041, Timisoara, Romania

${ }^{2}$ Victor Babes University of Medicine and Pharmacy Timisoara, Faculty of Pharmacy, $2^{\text {nd }}$ Eftimie Murgu Sq., 300041, Timisoara, Romania

${ }^{3}$ Romanian Academy - Institute of Chemistry Timisoara, Computational Chemistry Dept., $24^{\text {th }}$ Mihai Viteazu Blvd., 300223, Timisoara, Romania

Antibacterial gels offer an efficient hygiene in the absence of soap and water. The most part of these products are based on mixtures of different antibacterial and fungicide substances dissolved in an alcohol. Unfortunately, all cosmetic products containing alcohols wash the sebum and dry the skin. In the present study, alcohol-free antibacterial hydrogels were obtained through the synthesis of polyurethane (PU) microstructures with an increased amount of surfactant; 5-mercapto-1,2,4-triazole derivatives were used as active compounds inside the PU microstructures as antibacterial agents. There were studied: the $\mathrm{pH}$ of samples, the size and stability of PU microstructures, the skin irritation, sebum level and the hydration of stratum corneum using the mouse model and their efficiency against Escherichia coli. The results indicate that were obtained hydrogels with a slightly acid pH, PU microstructures with sizes between 185 and 265 $\mathrm{nm}$ and with a medium stability. It was found that these new antibacterial hydrogels do not produce an important modification of skin parameters (erythema, melanin, sebum and hydration of stratum corneum) and are efficient against $E$. coli.
\end{abstract}

Keywords: E. coli, erythema, pH, sebum, stratum corneum

Personal hygiene includes the daily routine that helps keep the body clean, which includes regular healthy habits as brushing teeth, washing hair and hands, cleaning of the body with soap and water, and wearing clean clothes. When people do not respect these habits and they are overlooked, the consequences can develop and generate different problems ranging from social to serious illnesses. In order to prevent these healthy problems, it is important to improve children's knowledge and skills by developing educational programs in kindergartens and schools [1]. Another important aspect in the personal hygiene is the correlation between the daily routine and socio-economic status. N. Colakoglu and L. Has have reported that poor oral hygiene can be associated with reduced income per capita, while the personal education status is directly proportional with the oral hygiene [2].

U.S. Food and Drug Administration, which is responsible for protecting the public health, published a rapport about the use of strong antibacterial products a few years ago [3]. They mention that people are always interested to buy commercial care products with big labels containing ANTIBACTERIAL term, and the safety of these products is not an important criterion for the customers. It is important to know the composition and the concentration of each component from such products because there are many chemical agents leading to skin irritations [4].

Antibacterial activity of different formulations based on triazole derivatives was already investigated by different research teams [5-6]. Triazoles are chemical compounds with a common skeleton based on a five-atom ring with two carbons and three nitrogen atoms $\left(\mathrm{C}_{2} \mathrm{H}_{3} \mathrm{~N}_{3}\right)$ (fig. 1).

The aim of this research was to obtain and to characterize different antibacterial hydrogels based on a polyurethane carrier containing different 5-mercapto-1,2,4triazole derivatives.

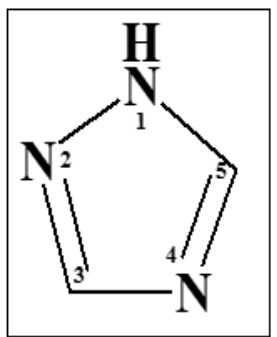

Fig. 1. Common skeleton of 1,2,4-triazole

\section{Experimental part}

Materials

Isophorone diisocyanate (IPDI) and polycaprolactone diol ( $P C L$, average $M \sim 530$ ) were purchased from SigmaAldrich. 1,4-Butanediol (BD) was obtained from Carl Roth $\mathrm{GmbH}$ (Germany). Polyethylene glycol (PEG, average $M_{\sim} \sim 200$ ) and solvent (acetone) were obtained from Merck (Germany). Emulsifier (Cremophor A25, known as Macrogol (25)-cetostearil eter) was kindly donated by our colleagues from University of Szeged (Hungary). The derivatives (1H-3-(4-ethoxyphenyl) -5-mercapto -1,2,4triazole, TZ53, 1H-3-(4-n- butoxyphenyl)- 5-mercapto 1,2,4- triazole, TZ55 and 1H- 3- styryl -5-mercapto -1,2,4triazole, TZ3a) were prepared and purified as described in another previous study [7].

All reagents were used withoutany previous purification.

\section{Synthesis of PU microstructures}

The protocol for obtaining of PU microstructures was already described by our team in previous papers [8-12]. It is a six-step procedure, as follows:

- the obtaining of the organic phase: $0.2 \mathrm{~g} 5$-mercapto1,2,4-triazole derivative and $2.0 \mathrm{~g}$ emulsifier (Cremophor 


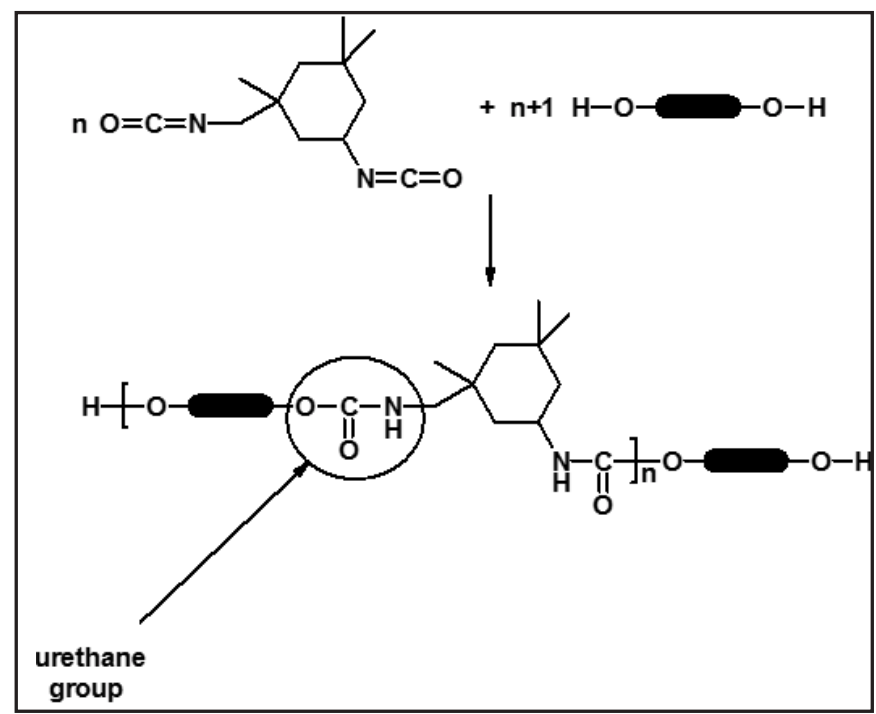

Fig. 2. Synthesis of PU chains

A25) were added to $20 \mathrm{~mL}$ solution $10 \%$ of IPDI in acetone and were magnetically stirred at $500 \mathrm{rpm}$ and $45^{\circ} \mathrm{C}$ for 1 hour;

- the obtaining of the aqueous phase: $40 \mathrm{~mL}$ aqueous solution $10 \%$ of $\mathrm{BD}, \mathrm{PCL}$ and PEG (2:4:1, volumes ratio) was magnetically stirred at $500 \mathrm{rpm}$ and $45^{\circ} \mathrm{C}$ for $1 \mathrm{~h}$;

- the mixing of phases: the organic phase is injected into the aqueous phase under magnetic stirring at $550 \mathrm{rpm}$ and $50^{\circ} \mathrm{C}$ (PU chains were formed in this phase) (fig. 2);

- the completion of the chemical reaction: stirring was continued for four hours at $50^{\circ} \mathrm{C}$ to ensure the maturation of structures walls;

- the purification of the products: the final suspensions were repeatedly washed and centrifuged using a wateracetone mixture $(1: 1, v / v)$;

- the drying of the products: borosilicate glass Petri dishes $100 \times 15 \mathrm{~mm}$ with thin layers of final products were maintained inside a PolEko SL115 laboratory oven for 6 hours daily at $85^{\circ} \mathrm{C}$ until the weight of every sample become constant (around $4-5$ days).

This procedure was repeated 4 times in order to obtain the following samples of PU microstructures: sample SO (without any triazole derivative), sample S1 (with TZ53), sample S2 (with TZ55), and sample S3 (with TZ3a).

\section{Analysis}

The $p H$ values of all synthesized products were determined in triplicate at the same concentration (aqueous solution, 1:500 w/v); a HI 2221 (Hanna Instruments, USA) containing a combined electrode was initially calibrated with three buffer solutions $(p H=3.00$, 8.00 , and respectively 10.00 , at $25^{\circ} \mathrm{C}$ ). The electrode was rinsed with water and dried prior to the measurements of samples. The electrode was then placed in a beaker containing $25 \mathrm{~mL}$ solution of every sample.

The same aqueous solutions of every sample (1:500 w/ v) were used for the investigation of polymeric structures' size and stability to the tendency of agglomeration; a Vasco Size-Analyzer and a Wallis Zeta-potential Device (Cordouan Technol., France) were used with the following parameters: for the Size-Analyzer (temperature: $25^{\circ} \mathrm{C}$, time interval: $24 \pm 3 \mu \mathrm{s}$, number of channels: $550 \pm 40$, laser power: $90 \pm 5 \%$, DTC position: UP, acquisition mode: continuous, analysis mode: Pade-Laplace) and for the Zetapotential Analyzer (plastic cuvette, temperature: $25^{\circ} \mathrm{C}$, medium resolution and Henry function: Smoluchowski).

Five-week old Balb/c Nude, homozygote, healthy male mice ( 2 mice/sample and 2 mice as control) were purchased from Charles River (Sulzfeld, Germany); they were kept in standard conditions: light-dark cycles, food and water ad libitum, almost constant temperature and humidity $\left(\sim 25^{\circ} \mathrm{C}\right.$ and $\left.\sim 60 \%\right)$.

Modern chemical analysis is based on novel techniques such as DSC, TG or DTG, HPLC, GC-MS, MALDI-TOF, FT-IR or FT-Raman [13]; in this study, non-invasive measurements of skin hydration, sebum, erythema values and melanin level were conducted using a Multiprobe Adapter System (MPA5) from Courage-Khazaka (Koln, Germany) containing the following probes: Corneometer ${ }^{\circledR} \mathrm{CM} 825$, Sebumeter ${ }^{\circledR} \mathrm{SM} 815$ and Mexameter ${ }^{\circledR} \mathrm{MX}$ 18. The twice weekly evaluations have started 1 week before any application of tested samples on the mice skin. The determinations of skin parameters were performed within 30 min after each application. The measurements were done in triplicate at the same moment of the day, by the same operator, in a narrow range of temperature $\left(24 \pm 1^{\circ} \mathrm{C}\right)$ and air humidity $(55 \pm 3 \%)$.

The efficacy against Escherichia coli was evaluated using a protocol described in e-Polymers five years ago [14]: every sample was treated with meat broth containing $0.1 \mathrm{ml}$ of E. coli culture and was thermostated at $37^{\circ} \mathrm{C}$. The number of cells was determined using a Thoma counting chamber by counting of the cells from 5 big squares and usage of the following formula:

$$
\text { Cells number }=\text { N. } 5 . I . D
$$

where $N$ is the cells number counted in 5 big square; 5 is the correction coefficient; I, the chamber height and D is the dilution correlation (equal with 1 in this case).

\section{Results and discussions}

The PU microstructures' solubility in water was evaluated prior the determination of $\mathrm{pH}$ using a procedure, which was al ready described in the literature by $H$.J. . eong [15]: $0.1 \mathrm{mg}$ sample is treated with distilled water to achieve different dilutions $(5 x, 10 x, 20 x, 50 x, 100 x)$. The presence of any gel-like suspension or precipitate was then analyzed in order to classify the obtained products. The experiment was done at $25 \pm 1^{\circ} \mathrm{C}$ and atmospheric pressure. It was found that the synthesized samples have the solubility below $0.6 \mathrm{mg} / \mathrm{mL}$.

Figure 3 exhibits the $\mathrm{pH}$ values recorded for the dilute aqueous solutions (1:500, w/v) of PU microstructures. The measurements were done in triplicate and average values are presented in figure. Lower $\mathrm{pH}$ values of samples containing PU structures loaded with 5-mercapto-1,2,4triazoles were observed and the reason probable is the acidic character of -SH groups; it is known that thiols $(\mathrm{pKa}=10)$ are more acidic than alcohols $(\mathrm{pKa}=16)$ [16]. Almost neutral or very weak acidic PU nano- and microstructures were obtained in our previous studies [17-21].

Many suspensions containing submicron particles have a complex size distribution with a broad dispersion (polydisperse systems), or they consist of several distinct particle populations of varying size (multimodal) [22]. The same dilute aqueous solutions of PU microstructures (1:500, w/v) were analyzed by a zetasizer to examine the size distribution (table 1). The zetasizer results implied that the average particle size was in micro scale (above 100 $\mathrm{nm}$ ). A slight aggregation of PU structures can be assumed due to the recorded Zeta-potential values which indicate a medium stability degree as stated in the scientific literature [23-26].

Visual observation remains one of the best methods of assessing skin characteristics, but a number of tools are currently available to reduce the interobserver variability [27]. Nowadays, tewameter, skin pH-meter, sebumeter, 


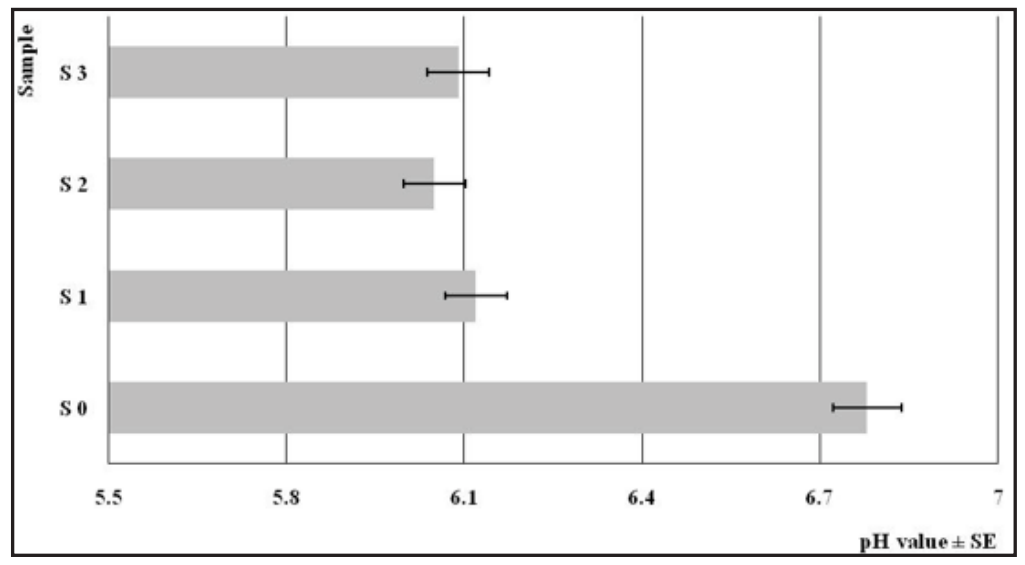

Fig. 3. The pH values of the samples

\begin{tabular}{|c|c|c|c|}
\hline \multirow{2}{*}{ Sample } & \multicolumn{2}{|c|}{ Particle size (nm) } & Zeta Potential (mV) \\
\cline { 2 - 3 } & Mean \pm SD & Polydispersity index & Mean \pm SD \\
\hline S 0 & $186 \pm 12$ & 0.2 & $32.3 \pm 3.5$ \\
\hline S 1 & $249 \pm 17$ & 0.4 & $28.3 \pm 2.7$ \\
\hline S 2 & $263 \pm 11$ & 0.5 & $25.3 \pm 3.1$ \\
\hline S 3 & $257 \pm 19$ & 0.4 & $29.8 \pm 2.9$ \\
\hline
\end{tabular}

Table 1

THE ZETASIZER CHARACTERIZATION mexameter, and corneometer measurements are noninvasive techniques used to evaluate the skin changes. The evolutions of average values that include main parameters such as melanin, erythema, sebum and hydration state of skin for each type of sample are shown in figure 4.

The skin of mice presents two important features: it is very sensitive and it has a penetration degree a few times greater than human skin [28]. So, the sensitivity of the mice skin is an advantage as it can be used as a parameter characterizing the investigational product harmfulness.

The Mexameter ${ }^{\circledR} \mathrm{MX} 18$ is a skin probe developed by Courage-Khazaka. It is enough to press the probe on the skin for just a few seconds and it records the melanin and erythema levels. The measurement is based on absorption/ reflection. The probe emits 3 specific light wavelengths and a receiver measures the light reflected by the skin; the melanin is measured by specific wavelengths chosen to correspond to different absorption rates by the pigments, while for the erythema measurement specific wavelengths are also used, corresponding to the spectral

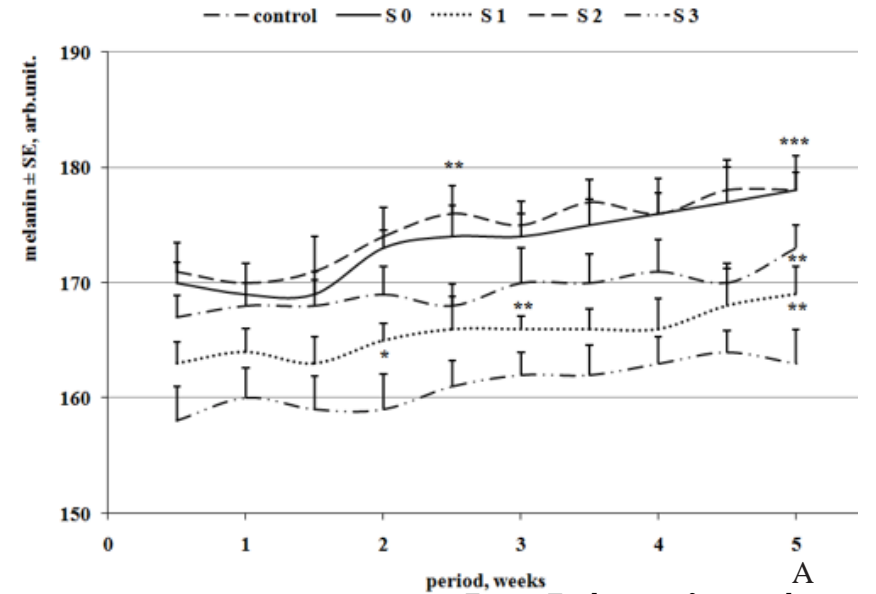

absorption peak of haemoglobin [29]. No important changes of melanin levels were observed in this experiment, all variations were between 158 and 178 (fig. $4 A)$, while the entire scale is between 0 and 999 arbitrary units. The mice skin presents a very rapid change of erythema values in the case of an irritative agent. The erythema values recorded in this five-week experiment have a very easily growing trend (between 70 and 105 units, fig. 4B) which can be associated with a normal trend for any skin treatment. This is the reason why it could be considered that these products are not irritative.

Sebum level is the main parameter in this study because other antibacterial hydrogels modify its value very much. This is the reason why we have chosen to represent any change of sebum level as percents. All the evaluated samples present a decrease of sebum level between 9 and $15 \%$ in 5 weeks, but it is important to mention that no major differences were observed between the samples containing PU microstructures with/without 5-mercapto1,2,4-triazole derivatives and the control sample (around $3 \%$ after 5 weeks compared to control, fig. $4 \mathrm{C}$ ).

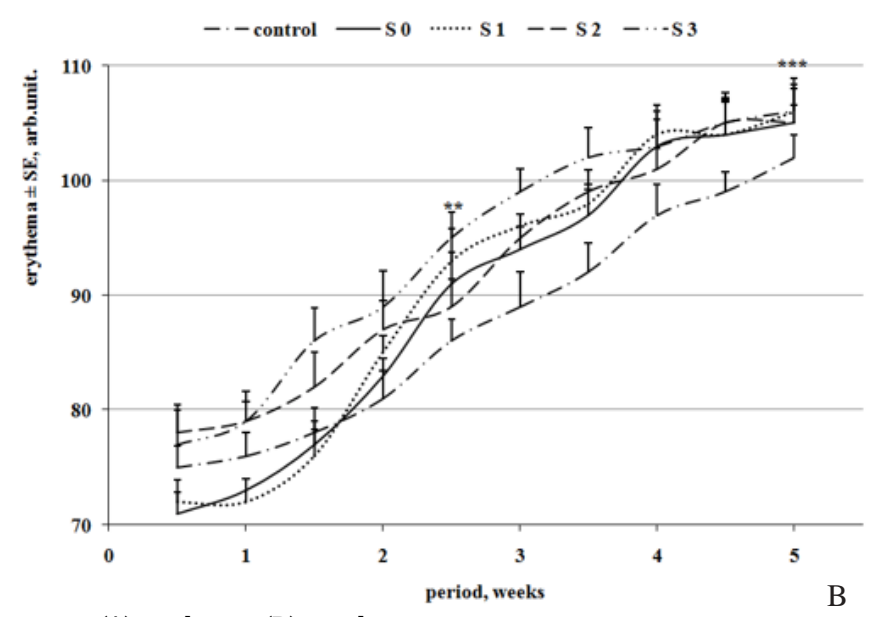

Fig. 4. Evolution of mice skin parameters: (A) melanin, (B) erythema $*$, ** and $* * *$ indicate $p<0.05, p<0.01$ and $p<0.001$ vs. control 

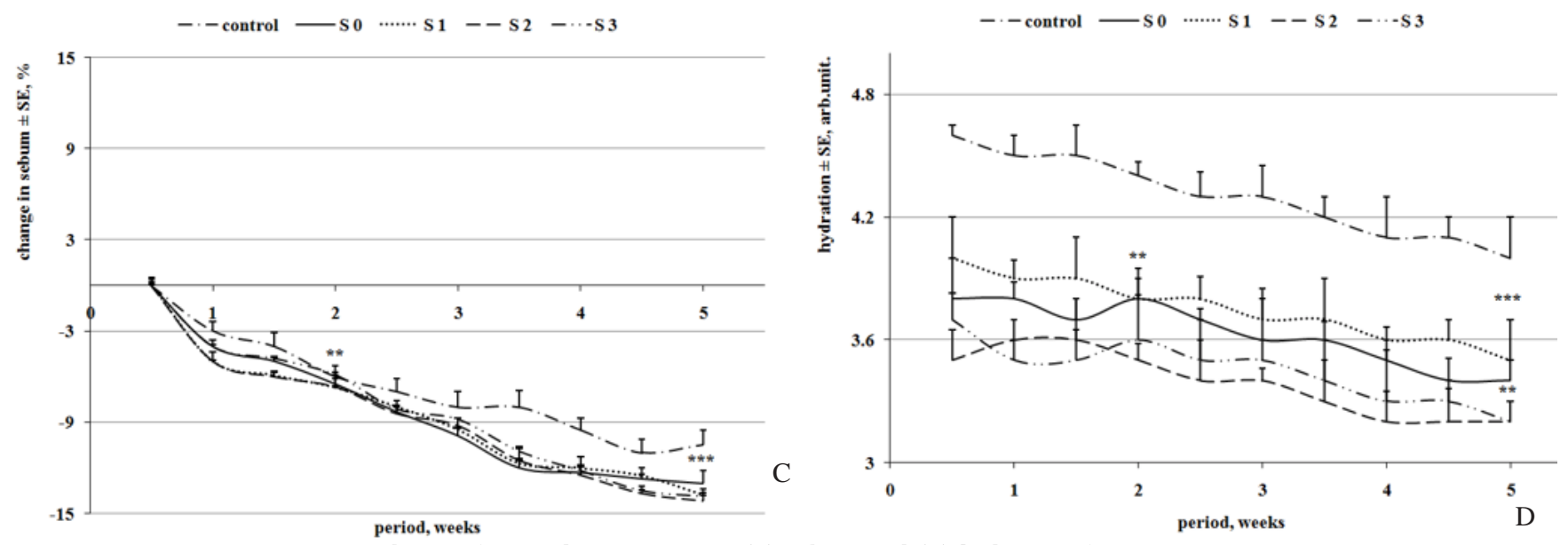

Fig. 4. Evolution of mice skin parameters: (C) sebum and (D) hydration of stratum corneum $*, * *$ and $* * *$ indicate $p<0.05, p<0.01$ and $p<0.001$ vs. control

\begin{tabular}{|c|c|c|c|c|}
\hline \multirow{2}{*}{ Sample } & \multicolumn{4}{|c|}{ Cell number after: } \\
\cline { 2 - 5 } & initial & l week & 4 weeks & 16 weeks \\
\hline S 0 & 498 & 480 & 689 & 471 \\
\hline S 1 & 527 & 65 & 89 & 90 \\
\hline S 2 & 541 & 51 & 74 & 79 \\
\hline S 3 & 534 & 57 & 69 & 73 \\
\hline
\end{tabular}

The measurement of hydration of stratum corneum, the skin surface, is based on the capacitance evaluation of a dielectric medium. The probe measures the change in the dielectric constant due to skin surface hydration changing the capacitance of a precision capacitor [29]. In this experiment it was observed that a treatment with our PU microstructures did not influence too much the hydration level of stratum corneum; the values are inside a narrow range, between 3.2 and 4.6 units for all determinations (fig. 4D).

A main difference can be observed between the effects of empty PU microstructures and of the other samples which contain 5-mercapto-1,2,4-triazole derivatives (table 2). The population dynamism inside a cells culture is influenced by many factors such as: the $\mathrm{pH}$ and the temperature during the incubation, the quality of broth, the loss of water volume due to the evaporation, the frequency of aeration etc. [30]. The decrease of cells number is nota linear one because the cellular rests become a nutritive layer for the other cells [14].

\section{Conclusions}

Antibacterial substances, known as bacteriocide or bactericide, kill bacteria and are grouped in three main categories: antiseptics (chlorine solutions, iodine preparations, peroxides and alcohols), disinfectants (active chlorine or oxygen, concentrated alcohols, surfactants and alkalis) and antibiotics (beta-lactam derivatives as penicillin derivatives and aminoglycosidics). Triazoles and their derivatives have a wide activity as antibacterial, antineoplastic, anti-inflammatory, anti-fungal and antitubercular agents. This study describes the obtaining and the biophysical characterization of a polyurethane drug delivery system containing different 5-mercapto-1,2,4triazole derivatives. The polymeric microstructures present low water solubility, a weak acidic $\mathrm{pH}$ of the dilute aqueous solutions, sizes between 185 and $265 \mathrm{~nm}$ and a medium stability to the tendency of agglomeration. No significant changes were observed to the assessment of skin parameters (melanin, erythema, sebum and skin hydration) after a five-w eek experiment; the samples with triazole derivatives exhibit an important antibacterial activity on Escherichia coli.

\section{References}

1. AYDOS, E.H., TUGRUL, B. Procedia - Social and Behavioral Sci., 186, 2015, p. 337.

2. COLAKOGLU, N., HAS, L. Procedia - Social and Behavioral Sci., 195, 2015, p. 1268.

3. US FDA. Antibacterial Soap? You Can Skip It - Use Plain Soap and Water. Available at: https://www.fda.gov. Last accessed: March 13th, 2017.

4. MENDES, B.R., SHIMABUKURO, D.M., UBER, M., ABAGGE, K.T. J. Pediatr. (Rio J.), 92, 2016, p. 290.

5. BARBUCEANU, S.-F., BANCESCU, G., SARAMET, G., RADULESCU, F.S., BARBUCEANU, F., SOCEA L.-I., BANCESCU, A. Farmacia, 64, 2016, p. 227.

6. ANSARI, K.F., LAL, C., KHITOLIYA, R.K. J. Serb. Chem. Soc., 76, 2011, p. 341.

7. BERCEAN, V.N., BADEA, V., SISU, E., BINDILA, L., CSUNDERLIK, C. Rev. Chim. (Bucharest), 54, 2003, p. 368.

8. JUMANCA, D., GALUSCAN, A., PODARIU, A.C., BORCAN, F., EARAR, K. Rev. Chim. (Bucharest), 65, 2014, p. 1473.

9.DANCIU, C., BORCAN, F., SOICA, C., ZUPKO, I., CSANYI, E., AMBRUS, R., MUNTEAN, D., SASS, C., ANTAL, D., TOMA, C., DEHELEAN, C. Nat. Prod. Comm., 10, 2015, p. 951.

10.CITU, C., CEUTA, L., POPOVICI, R., IONESCU, D., PINZARU, I., BORCAN, F. Mat. Plast., 52, 2015, p. 553.

11. OPREAN, C., ZAMBORI, C., BORCAN, F., SOICA, C., ZUPKO, I., MINORICS, R., BOJ IN, F., AMBRUS, R., MUNTEAN, D., DANCIU, C., PINZARU, I.A., DEHELEAN, C., PAUNESCU, V., TANASIE, G. Pharm. Biol., 54, 2016, p. 2714. 
12. OPREAN, C., BORCAN, F., PAVEL, I., DEMA, A., DANCIU, C., SOICA, C., DEHELEAN, C., NICU, A., ARDELEAN, A., CRISTEA, M., IVAN, A., TATU, C., BOJ IN, F. In Vivo, 30, 2016, p. 633.

13. CINTA-PINZARU, S., DEHELEAN, C.A., SOICA, C., CULEA, M., BORCAN, F. Chem. Cent. J., 6, 2012, p. 67.

14. BORCAN, F., BOLCU, C., FILIMON, N., BANDUR, G. e-Polymers, 080, 2012, p. 01.

15. JEONG, H.J ., CHAI, H.B., PARK, S.Y., KIM, D.S. Bioorg. Med. Chem. Lett., 9, 1999, p. 1201.

16. GUPTA, B., ANJUM, S., IKRAM, S.J. Appl. Polym. Sci., 129, 2013,

p. 815.

17. BORCAN, F., SOICA, C.M., GANTA, S., AMIJI, M.M., DEHELEAN, C.A., MUNTEANU, M.F. Chem. Cent. J., 6, 2012, p. 87.

18. BORCAN, F., SOICA, C.M., DEHELEAN, C.A., GANTA, S., AMIJI, M.M. Rev. Chim. (Bucharest), 63, no. 11, 2012, p. 1164.

19. HEGHES, A., SOICA, C.M., ARDELEAN, S., AMBRUS, R., MUNTEAN, D., GALUSCAN, A., DRAGOS, D., IONESCU, D., BORCAN, F. Chem. Cent. J., 7, 2013, p. 66.

20. GALUSCAN, A., JUMANCA, D., BORCAN, F., SOICA, C.M., IONESCU, D., RUSU, L.C., CRAINICEANU, Z. Rev. Chim. (Bucharest), 65, no. 2, 2014, p. 190.

21.CITU, I.M., BORCAN, F., ZAMBORI, C., TITA, B., PAUNESCU, V., ARDELEAN, S. Rev. Chim. (Bucharest), 66, no. 1, 2015, p. 119.
22. ANDERSON, W., KOZAK, D., COLEMAN, V.A., JAMTING, A.K., TRAU, M. J. Colloid. Interface Sci., 405, 2013, p. 322.

23. SALOPEK, B., KRASI, D., FILIPOVI, S. Rudarsko-geoloiko-naftni zbornik, 4, 1992, p. 147.

24. MUNTEANU, M.F., ARDELEAN, A., BORCAN, F., TRIFUNSCHI, S.I., GLIGOR, R., ARDELEAN, S.A., CORICOVAC, D., PINZARU, I., ANDRICA, F., BORCAN, L.-C. Curr. Drug Delivery, 14, 2017, (E-pub Ahead of Print).

25.CITU, I.M., TOMA, C., TRANDAFIRESCU, C., ANTAL, D., ZAMBORI, C., OPREAN, C., BOJIN, F., BORCAN, F., PAUNESCU, V., LAZUREANU, V., Rev. Chim. (Bucharest), 66, no. 3, 2015, p. 431.

26. TRANDAFIRESCU, C., LEDETI, I., CORICOVAC, D.E., SOICA, C.M., PINZARU, I., DEHELEAN, C.A., IACOB, R.E., BORCAN, F. Mat. Plast., 53, no.2, 2016, p. 205.

27. TAYLOR, S., WESTERHOF, W., IM, S., LIM, J. J. Am. Acad. Dermatol., 54,2006, p. S282.

28. MORTENSEN, L.J ., OBERDORSTER, G., PENTLAND, A.P., DELOUISE, L. Nano Lett., 8, 2008, 2779.

29. Courage-Khazaka Scientific Devices Manual. Available at: http:// www.courage-khazaka.de. Last accessed: March 13th, 2017.

30. FINKEL, S.E., KOLTER, R. Proc. Natl. Acad. Sci. USA, 96, 1999, p. 4023.

$\overline{\text { Manuscript received: } 6.01 .2017}$ 